\title{
The Effects of Labor Shortages on Starting Salaries for Sex-Typed Jobs*
}

By: E. Holly Buttner and Benson Rosen

Buttner, E. H. \& Rosen, B. (1987). "The Effects of Labor Shortages on Starting Salaries for SexTyped Jobs.” Sex Roles, 17, 59-71.

Made available courtesy of SPRINGER VERLAG GERMANY:

http://springerlink.metapress.com/content/101600/

***Note: Figures may be missing from this format of the document

\begin{abstract}
:
An experimental simulation was conducted to examine potential differences in sensitivity to forces to supply and demand among male and female sex- typed jobs. Respondents faced with a labor shortage favored raising salaries for male sex-typed jobs, but favored alternatives to salary increases for female sex-typed jobs at entry and middle levels Findings are discussed in terms of occupational sex stereotypes and differing perceptions regarding the urgency and difficulty of filling vacancies in male and female positions.
\end{abstract}

\section{Article:}

In 1963, when the Equal Pay Act was passed, women earned on average 60 cents for every dollar earned by men More than 20 years later, in 1986, the Bureau of Labor statistics reported that women still averaged only 69 cents for every dollar earned by men (Green \& Epstem, 1986). In recent years, women's rights groups, legislators, and some labor unions have worked to further reduce the pay gap between the sexes. Much of the effort to achieve pay equity between men and women has coalesced around comparable worth pay policies.

Under a comparable worth policy, jobs evaluated to be equally valuable on dimensions such as effort, skill, and responsibility would be compensated equally (Schwab, 1980). For example, if evaluated to have the same worth, positions as dissimilar as truck driver and secretary would be paid the same, regardless of the prevailing market wages for these jobs. In other words, proponents of comparable worth argue for greater emphasis on internal equity and less emphasis on external equity in setting salaries within an organization (Treiman \& Hartman, 1981).

Opponents of comparable worth advocate setting salaries based on labor market forces of supply and demand. (For an excellent review of various positions on comparable worth, see Gold, 1983.) They assert that the external labor market operates efficiently and without bias with respect to the sex of the job holder (Hildebrand, 1980) A central question in the comparable worth controversy and one addressed in the present study concerns the degree to which salaries for predominantly male and female sex-typed job are equally influenced by market forces of supply and demand.

\footnotetext{
${ }^{*}$ Portions of this study were presented at the National Academy of Management Meetings, Chicago, 1986
} 
Labor Attorney Winn Newman, commenting on employers' assertions that the labor market determines wages, challenged the free market theory of wage determination (Newman, 1984) According to Newman:

Another major objection raised by employers in wage discrimination suits us that job evaluation does not set wages Rather it is "the market" that sets wages, and "the market" is a sacred cow But there is no objective market concept that fleshes out wages for various jobs Reliance on the market to set wages is characterized by so many variables that it could mean something different to virtually every employer The employer decides whom to survey, what kind of survey, which jobs to survey and so on (p 90)

Comparable worth advocates assert that employers respond differently to labor shortages in male and female occupations (Hartman, Roos, \& Treiman, 1985). Bergmann (1985) argues that employers are more sensitive to forces of supply and demand in predominantly male positions, and more willing to raise salaries when demand exceeds supply for male jobs When demand exceeds supply in predominantly female positions, on the other hand employers resist raising salaries. Using econometric models of the labor market, Killingsworth (1985), showed that females, particularly women in segregated occupations, could be assigned lower salaries. However, there have been no empirical studies of the influence of job sex type on salary assignment in the context of a labor shortage.

Human resource shortages in female positions may be resolved by other strategies, including subcontracting, job redesign, automation, or foreign recruiting For example, North Carolina Secretary of Administration, Jane Smith Patterson, recently described employers' reactions to a nursing shortage (Patterson, 1984):

A few years ago, an acute shortage of nurses existed According to the free market theory, employers would have raised salaries In theory, a substantial boost in salaries would attract more potential nurses to meet the shortage But employers increased nurses' salaries only slightly, meanwhile they cut nursing services, adjusted nurses' hours and spend large sums recruiting nurses overseas The nursing profession remained virtually all women (97 percent) who made on average $\$ 17,300$ (p 26)

Hartman et al. (1985) also cited hospitals as using signing bonuses and foreign recruiting to cope with nursing shortages without raising starting salaries.

Similar nationwide shortage of school teachers have been reported (Mackay-Smith, 1985). Responses by school administrators to these shortages include recruiting from Mexico, Canada, and Ireland; lowering entrance requirements; and only as a last resort, raising salaries.

According to Stanley (1983), another strategy employers have adopted to deal with shortages in female-dominated occupations is to redesign or automate predominantly female positions Stanley cites job redesign, simplification, and ultimate job loss in such predominantly female positions as stenographer, bank teller, insurance clerk, and key punch operator.

Mounting anecdotal evidence suggests that employers respond differently to labor shortages in male and female positions. A number of researchers (Milkovich, 1980; Schwab, 1980; Schwab \& Wichern, 1983) have called for the study of the process by which supply and demand for labor in sex-typed occupations is translated into salaries and wages. Yet no study to date has systematically investigated the extent to which economic forces of supply and demand can be 
distorted by sex bias. Accordingly, a study was designed to examine the use of employer reactions to labor shortages in predominantly male and predominantly female jobs. The study tested the following hypothesis: Under conditions of a human resource shortage, participants will be more likely to assign a salary increase for male-dominated jobs while for female dominated jobs participants will be more likely to recommend an alternative such as a change in technology, job redesign, or recruitment from foreign labor markets.

\section{METHODS}

We examined the potential influence of Job sex type on recommendations for resolving a labor shortage in the context of a human resource management simulation.

\section{Experimental Design}

The effects of job sex type on resolving a labor shortage was examined across three organizational levels. Accordingly a 3 x 3 experimental design was created.

Job Sex Type. Job sex type was manipulated at three levels. predominantly male job, predominantly female job, and neutral Job. Krefting, Berger, and Wallace (1978) showed that occupational stereotypes are largely based on the percentages of males and females in an occupation. Female sex-typed jobs selected for study were registered nurse, nursing aide, and telephone operator. Women hold $90 \%$ of all nursing positions and $93 \%$ of telephone operator positions (Mellor, 1984) The male sex-typed jobs selected for study were engineer (95\% male), tool and die maker (99\% male), and telephone installer (92\% male). The sex-neutral Jobs selected for study were accountant, assistant buyer, and assembler, which are $40 \%, 48 \%$, and $55 \%$ female, respectively.

Job Level. The major question of interest is how job sex type influences reactions to labor shortages. However, by examining sex-typed Jobs across three organizational levels, the generality of the sex-typed job effects can be assessed. Accordingly, the organizational level of the three sex-typed positions also was manipulated Three job levels were created; entry level, middle level, and professional level.

The selection of jobs at three organizational levels was based on Treiman's (1977) job prestige scale. Entry-level jobs of telephone operator, telephone installer, and assembler were of comparable prestige Similarly, the three middle level positions - tool and die maker, occupational nurse assistant, and assistant buyer-were at the same approximate prestige level. Finally, the three professional-level positions - registered nurse, engineer, and accountant — were at similar prestige levels.

Strategies for Resolving the Labor Shortage The major dependent variables were respondents' evaluations of four strategies for resolving the labor shortage described in the human resource management simulation On the basis of reports in the scientific and popular press, the following four options were created. (1) salary increase to attract more applicants; (2) job redesign and simplification to attract applicants with lower qualifications; (3) recruiting outside the local labor market, including overseas, and (4) automation to reduce labor needs. 
Participants. Participants in the human resource management simulation were 105 undergraduate busmess students attending a large Southeastern university ( 24 males, 77 females, and 4 who failed to identify their sex) Fifty eight percent of the respondents were currently working full or part time.

\section{Procedure}

Respondents received an experimental packet in which they were asked to assume the role of a personnel administrator for a high-technology company. The company was described as experiencing a shortage of qualified applicants for one of its positions.

Respondents read a job description and a summary of the unsuccessful recruiting strategy by the company for that job. Respondents then read a description of the four human resource strategies proposed as possible alter- 'natives to resolve the labor shortage. These strategies were an increase in salary, a change $\mathrm{m}$ technology, job redesign, and foreign recruitment.

Participants were told that the relative costs of each option were approximately the same. Evaluation of each option was made on a 6-point scale, ranging from (1) strongly recommend to (6) strongly oppose. After evaluating each option, respondents were asked to select the option that they judged to be most effective for resolving the labor shortage problem Finally, as a check on the manipulation of job sex type and job level, respondents completed a brief postexperimental questionnaire.

In summary, the study was designed to investigate how job sex type influences recommendations for resolving a labor shortage at three organizational levels. Participants read about a labor shortage in either a male, female, or neutral position at either an entry, middle, or professional level, and evaluated four human resource strategies for resolving the shortage. Participants received only one version of the simulation and were not aware that other versions existed.

\section{RESULTS}

\section{Manipulation Check}

In the postexperimental questionnaire, perceptions of job sex type were measured on a 6-point scale ranging from (1) masculine to (6) feminine The male positions perceived an average rating of 257 , the neutral positions received an average rating of 3.34, and the female positions received an average rating of $4.56(\mathrm{~F}=15.53, \mathrm{p}<01)$. It appears the manipulation of job sex type was successful.

As a check on the organizational level manipulation, respondents were asked to rate the position described in the simulation according to organizational level. Respondents recorded their ratings on a 6-point scale ranging from (1) low-level position to (6) high-level position Average evaluations on the organizational level scale were 230 for entry level positions, 3.57 for middlelevel positions, and 4.52 for professional-level positions $(\mathrm{F}=10.21, \mathrm{p}<.01)$. It appears the manipulation of organizational level was successful. We hypothesized that the laws of supply and demand in the labor market do not influence compensation policies similarly for predominantly male and predominantly female positions. Specifically, for male jobs, we predicted that the recommended strategy for coping with labor shortages would be to 


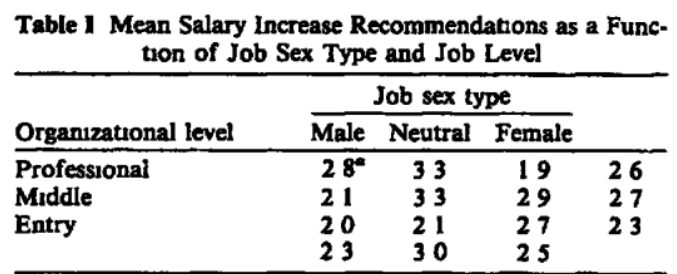

Analysis of variance of salary increase recommendations

\begin{tabular}{lcccc}
\hline Source & $d f$ & Mean & $F$ & $p$ \\
\hline Job sex type (A) & 2 & 30108 & 195 & 1478 \\
Organizational level (B) & 2 & 19189 & 124 & 2930 \\
A X B & 4 & 40560 & 263 & 0392 \\
\hline ascale 1, strongly recommend, & 6 , strongly oppose salary \\
increase
\end{tabular}

increase salaries. For female positions, we predicted that labor shortages would lead to recommendations for foreign recruiting, job redesign, or automation.

\section{Salary Recommendations}

Recommendations for raising salaries in response to labor shortages for sex-typed and sexneutral jobs at three organizational levels are shown in Table I. Analysis of variance for salary recommendations yielded no significant main effects for either job sex type or organizational level. However, a significant Job Sex Type x Job Level interaction effect was found $(\mathrm{F}=4$ 06,p $<04)$.

The significant Job Sex Type x Organizational Level interaction effect is illustrated in Fig. 1 It is clear from Fig. 1 that recommendations for salary increases varied as a function of both job sex type and organizational level For entry- and middle-level jobs, participants favored salary increases more for male than for female positions $(t=205, \mathrm{p}<05)$ This finding is consistent with our hypothesis. For professional-level jobs, participants favored salary increases more for female compared to male positions $(I=215, \mathrm{p}<.05)$. Findings at the professional level are contrary to our hypothesis.

\section{Alternative Human Resource Strategies}

We also examined potential differences in the degree to which Job sex type and organizational level influenced recommendations to adopt three alter- 


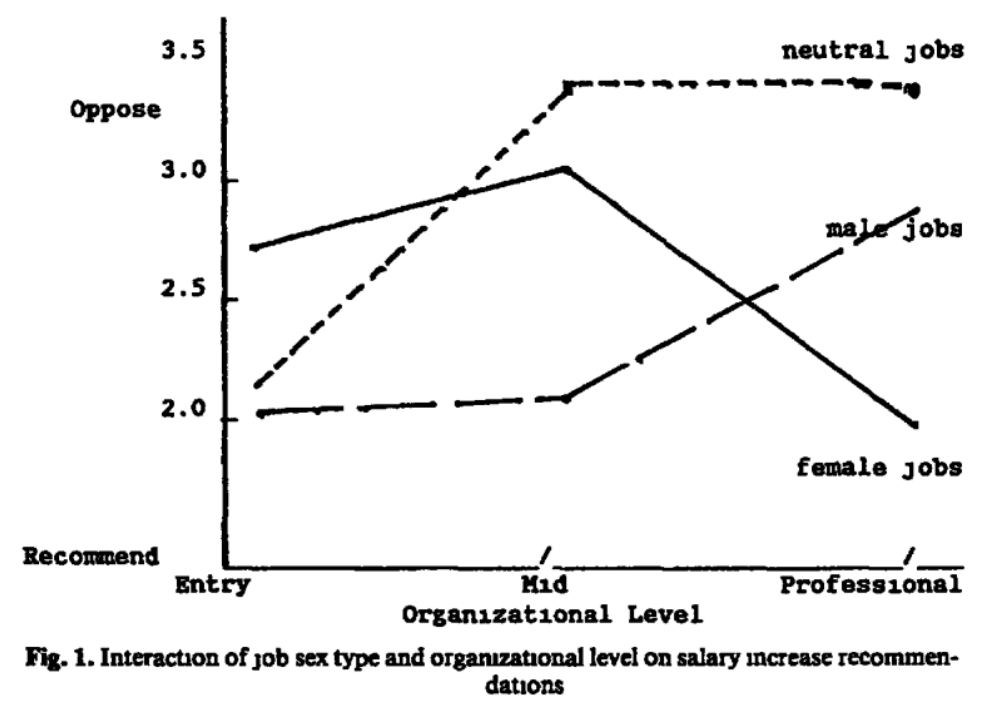

native strategies for coping with a labor shortage. Analyses of variance on recommendations for adopting job redesign, foreign recruiting, and automation failed to yield any significant main or interactive effects. Respondents tended to favor the job redesign strategy most as an alternative to a salary increase. The automation strategy was rated lower than job redesign. Foreign recruiting was the least favored option for resolving the labor shortage.

\section{Selection of Preferred Option}

After evaluating each option, participants selected one option for resolving the labor shortage problem. Participants' choice of options is shown in Table II.

We hypothesized that participants would chose the salary increase option for dealing with a labor shortage in a male job and an alternative to salary increase for a female job. Across all three organizational levels, salary increases were recommended by $53 \%$ of participants for the male jobs and by $42 \%$ of participants for the female jobs. Although the finding was in the predicted direction, the difference was not significant For entry-level positions, 50\% of participants in the male job condition chose the salary increase option compared to only $10 \%$ in the female job condition. Similarly, for middle-level jobs, $62 \%$ recommended salary increases for the male job compared to $55 \%$ for the female job. Although the difference in reconunen-

Table II Number (Percentage) of Respondents Choosing Salary Increase or Alternative Option Across Experimental Conditions

\begin{tabular}{|c|c|c|c|c|c|c|c|c|c|}
\hline & \multicolumn{9}{|c|}{ Job sex type } \\
\hline & \multicolumn{3}{|c|}{ Male } & \multicolumn{3}{|c|}{ Neutral } & \multicolumn{3}{|c|}{ Female } \\
\hline & $\begin{array}{l}\text { Entry } \\
\text { level }\end{array}$ & $\begin{array}{c}\text { Middle } \\
\text { level }\end{array}$ & $\begin{array}{c}\text { Professional } \\
\text { level }\end{array}$ & $\begin{array}{l}\text { Entry } \\
\text { level }\end{array}$ & $\begin{array}{c}\text { Middle } \\
\text { level }\end{array}$ & $\begin{array}{c}\text { Professional } \\
\text { level }\end{array}$ & $\begin{array}{l}\text { Entry } \\
\text { level }\end{array}$ & $\begin{array}{c}\text { Middle } \\
\text { level }\end{array}$ & $\begin{array}{c}\text { Professional } \\
\text { level }\end{array}$ \\
\hline $\begin{array}{l}\text { Options } \\
\text { Salary increase }\end{array}$ & $\begin{array}{c}6 \\
(50 \%)\end{array}$ & $\begin{array}{c}8 \\
(62)\end{array}$ & $\begin{array}{c}7 \\
(50 \%)\end{array}$ & $\begin{array}{c}4 \\
(50 \%)\end{array}$ & $\stackrel{2}{(17)}$ & $\begin{array}{c}4 \\
(36)\end{array}$ & $\begin{array}{c}1 \\
(10 \%)\end{array}$ & $\begin{array}{c}6 \\
\text { (55) }\end{array}$ & $\begin{array}{c}7 \\
(58)\end{array}$ \\
\hline Other & $\begin{array}{c}6 \\
(50 \%)\end{array}$ & $\stackrel{5}{(38)}$ & $\begin{array}{c}7 \\
(50 \%)\end{array}$ & $\begin{array}{c}4 \\
(50 \%)\end{array}$ & $\begin{array}{c}10 \\
83\end{array}$ & $\begin{array}{c}7 \\
(64)\end{array}$ & $\stackrel{9}{9}$ & $\begin{array}{c}5 \\
(45)\end{array}$ & $\stackrel{5}{(42)}$ \\
\hline
\end{tabular}


dations appears to support our hypothesis that male jobs would be favored over female Jobs for salary increases, the difference did not reach statistical significance $\left(x^{2}=2.36, p<.12\right)$. While the pattern of recommendations was in the predicted direction at the entry and midorganizational levels, the small sample size may not have provided sufficient power to detect potential significant differences.

At the professional level, we found a tendency to choose the salary increase option more frequently for the female sex-typed job (58\%) compared to the male sex-typed (50\%), and the neutral job (35\%). However, this difference also was not significant.

\section{Sex of Respondent}

The findings of previous research investigations have yielded inconsistent results regarding the sex of the participants on personnel decisions. Arvey, Passino, and Loundsbury (1977) found that, in a job analysis exercise, female participants described the job they were analyzing slightly more positively than did males. Other studies (Beattie \& Diehl, 1979; Grams \& Schwab, 1985) have found no significant differences in decisions among male and female participants. To learn more about the influence of gender on personnel decisions, we examined the effects of respondent's sex on evaluations of the four options. For the salary increase option, female respondents favored an increase more strongly than did male respondents (mean females $=2.42$, mean males $=3.08 ; \mathrm{F}=551, \mathrm{p}<.02$ ). However, sex of respondent did not interact with job sex type or organizational level to influence salary increase recommendations. No significant main or interaction effects were found for sex of respondent on evaluations of the other three options.

In summary, the study findings indicate that recommendations for resolving a labor shortage are complex, depending upon both the sex type of the job and the organizational level of the vacant position. Our hypothesis that in the event of a labor shortage salary increases would be favored more for male jobs than for female jobs was supported for entry- and middle- level positions, but not for professional positions, for evaluations of the salary option. Findings for choice of option were in the predicted direction, but failed to reach statistical significance.

\section{DISCUSSION}

Opponents of a comparable worth compensation philosophy have emphasized the merits of determining wages on the basis of economic principles of supply and demand. They argue that a major cause of the pay gap between the sexes is due to the clustering of women into a small number of "occupational ghettos." Accordingly, the large number of women available to work in these positions keeps salaries low (Gold, 1983).

Proponents of comparable worth argue that salaries in traditionally male jobs compared to salaries in traditionally female jobs are more sensitive to supply and demand Proponents of comparable worth cite anecdotal evidence that even in the face of labor shortage in traditionally female positions such as secretary, teacher, or nurse, salaries increase only slightly. Rather, administrators attempt to find alternatives such as job simplification, automation, or foreign recruiting to resolve labor shortages in female positions The present study systematically investigated the sensitivity of salaries in traditionally male and female positions to labor shortages. 
Our findings suggest that in the event of labor shortages, job sex type does influence decisions to raise salaries depending upon the organizational level of the job. When asked to choose among alternative strategies for coping with a labor shortage, a salary increase to attract qualified applicants was the preferred strategy. However, raising salaries was significantly more strongly recommended for coping with a labor shortage in traditionally male jobs compared to traditionally female jobs at entry and mid-organizational levels. Differences in sensitivity to principles of supply and demand were particularly obvious for entry-level positions. While the small sample size precluded a realistic test of differences, only $10 \%$ of our participants elected to raise salaries for an entry-level, traditionally female position compared to $50 \%$ who recommended raising salaries for an entry-level male position. Accordingly, there was some support for the hypothesis that compared to male sex-typed jobs, female sex-typed jobs are less sensitive to supply and demand forces in the labor market.

It is interesting to note that, for professional level positions, raising salaries was favored in female compared to male positions. At professional levels, perceptions of the value of women's work may be sufficiently high so as not to preclude the possibility of raising salaries in order to attract more applicants.

We can only speculate on the explanation for these findings Researchers have thoroughly documented the influence of sex stereotypes on a range of managerial selection, promotion, and compensation decisions (e.g., Gerdes \& Gerber, 1983, Rosen \& Jerdee, 1973, 1974; Rosen \& Mende, 1979). Perhaps sex stereotypes regarding what various male and female jobs are worth influenced choices among options for coping with labor shortages Recent research by Grams and Schwab (1985) illustrates how knowledge about the current market wage for a position influences the number of job evaluation points assigned to that position. Stereotypes regarding the "value" of entry- and middle-level traditionally female jobs may have influenced decisions to avoid increasing salaries and to seek alternative approaches for coping with a low supply-high demand employment situation.

A second explanation for the differences in sensitivity to force of supply and demand among male and female jobs may be based on respondents' perceptions regarding the urgency or anticipated difficulty of filling these positions. While experimental materials indicated that the acuteness of the labor shortage was identical in the male and female jobs, respondents may have assumed that filling male jobs would be more difficult and thus require higher starting salaries. For example, respondents may have judged it more likely to find female compared to male employees on an emergency or fill-in basis from temporary help agencies Similarly, respondents may have perceived that the majority of male applicants already would be employed. Accordingly, higher salaries would be needed as an inducement before men would consider changing employers. Female applicants, on the other hand, may have been seen as more equally divided among currently employed women and women temporarily outside of the labor force (e $\mathrm{g}$, engaged in child care or volunteer work). Perhaps respondents felt a higher financial incentive was needed to attract males from other jobs then to attract females considering reentry into the labor force.

Note also that salary decisions are made by men in most organizations. Findings indicate that male participants were less enthusiastic compared to female participants in recommending salary 
increases to resolve a labor shortage This finding is consistent with recent survey research, which reports a consistent pattern of sex differences among executives on how to reduce the salary gap between traditionally male and female jobs (Rosen, Rynes, \& Mahoney, 1983). The reluctance of males to raise salaries $m$ the face of labor shortages could perpetuate the problems of women who choose to work in traditionally female occupations.

When taken together, our pattern of findings suggest that, relative to comparable male positions, many traditionally female jobs such as clerical, light assembly, telephone operator, nurse, and librarian positions may be less sensitive to principles of supply and demand. Increasing the sensitivity to market forces of female entry- and middle-level Jobs may depend upon more men moving into these traditionally female positions.

Our conclusions are highly tentative and must be tested further. Our sample of decision makers consisted of business students. Note, however, that business students and business professionals were used as paired samples in a number of studies in the context of personnel decision making (Bernstein, Hakel, \& Harlan, 1975; Dipboye, Fromkin, \& Wiback, 1975; Hakel, Dobmeyer, \& Dunnette, 1970; Landy \& Bates, 1973). In these studies, the two groups responded in essentially similar ways. The only consistent difference was a leniency bias on the part of students Moreover, in the context of sex role stereotyping of occupations, Krefting et al. (1978) found that business students and business professionals share similar views of sex type as a function of the gender of job incumbent. In addition, business students and managers have provided similar estimates of appropriate salary differentials between jobs (Mahoney, 1979). Of course, generalizations from this study must be made with caution. Replications using personnel professionals as decision makers represents an important extension of the present research.

Given projections of rapid growth during the next decade in demand for such traditional female occupations as registered nurse (49\% increase), elementary school teacher ( $37 \%$ increase), secretary ( $25 \%$ increase) and sales clerk (24\% increase), the prospects of labor shortages in these occupations are very real How management responds to these critical human resource problems deserve further systematic study.

\section{REFERENCES}

Arvey, R , Passim, E , \& Loimdsbury, I Job analysis results as influenced by sex of incumbent and sex of analyst Journal of Applied Psychology, 1977, 62, 411-416

Beattie, M , \& Diehl, L Effects of social conditions on the expression of sex-role stereotypes Psychology of Women Quarterly, 1979, 4, 241-255

Bergmann, B The economic case for comparable worth In H Hartman (Ed ), Comparable worth New directions for research Washington, D C National Academy Press, 1985

Bernstein, V , Hakel, M D , \& Harlan, A The college student as interviewer A threat to generalizability? Journal of Applied Psychology, 1975, 60, 266-268

Dipboye, R , Fromkin, H , \& Wiback, IC Relative importance of applicant sex, attractiveness, and scholastic standing in evaluation of job applicant resumes Journal of Applied Psychology, 1975, 60, 39-43

Gerdes, E \& Gerber, D Sex bias in hiring Effects of job demands and applicant competence Sex Roles, 1983, 9, 307-317. 
Gold, M A debate on comparable work Ithaca, NY Industrial and Labor Relations Press, 1983 Grams, $\mathrm{R}, \&$ Schwab, D P An investigation of systematic gender-related error in job evaluation Academy of Management Journal, 1985, 28, 279-290

Green, O , \& Epstein, R (Eds ), Employment and earnings, Washington, DC US Department of Labor, Bureau of Labor Statistics, 1986

Hakel, M Dobmeyer, T \& Dunnette, M Relative importance of three content dimensions in overall suitability of job applicants' resumes Journal of Applied Psychology, 1970, 54, 65-71

Hartman, H, Roos, P , \& Treiman, D An agenda for basic research on comparable worth In Hartman (ed ), Comparable worth New directions for research Washington, D C National Academy Press, 1985

Hildebrand, 0 The market system In R Livernash (Ed ), Comparable worth Issues and alternatives Washington, D C Equal Employment Advisory Council, 1980

Killingsworth, M The economics of comparable worth Analytical, empirical, and policy questions In H Hartman (Ed ), Comparable worth New directions for research Washington, D C National Academy Press, 1985

Krefting, P , Berger, P K , \& Wallace, M J The contribution of sex distribution, job content, and occupational classification to job sex typing two studies Journal of Vocational Behavior, 1978, $13,181-191$

Landy, F , \& Bates, F Another look at contrast effects $m$ the employment interview Journal of Applied Psychology, 1973, 58, 141-144

Mackay-Smith, A A student boom makes teachers a prized catch Wall Street Journal, June 20, 1985, 205, 31

Mahoney, T Organizational hierarchy and position worth Academy of Management Journal. 1979, 22, 726-737

Milkovich, G. T The emerging debate In E R Livernash (Ed ), Comparable worth Issues and alternatives Washington, D C Equal Employment Advisory Council, 1980

Mellor, E F Investigating the differences in weekly earnings of women and men Monthly Labor Review, 1984, 107, 17-29

Newman, W Comparable worth Issues for the 80s Proceedings of the U S Commission on Civil Rights, Washington, D C , 1984.

Patterson, J. S The new frontier for women (and men) North Carolina Insight, 1984, 7, 22-31.

Rosen, B , \& Jerdee, T H The influence of sex-role stereotypes on the evaluation of male and female supervisory behavior Journal of Applied Psychology, 1973, 57, 44.48

Rosen, B \& Jerdee, T H Influence of sex-role stereotypes on personal decisions Journal of Applied Psychology, 1974, 59. 9-14

Rosen, B , \& Mende, M F Influence of strong versus weak fair employment policies and applicant's sex on selection decisions and salary recommendations in a management simulation Journal of Applied Psychology, 1979, 64. 435-439

Rosen, B , Rynes, S \& Mahoney, T A Compensation, Jobs, and gender Harvard Business Review, 1983, 61, 170-178

Schwab, D P Job evaluation and pay setting Concepts and practices In E F Livernash (Ed), Comparable worth- Issues and alternatives Washington, D C Equal Employment Advisory Council, 1980

Schwab, D P , \& Wichern, D W Systematic bias in job evaluation and market wages Implications for the comparable worth debate Journal of Applied Psychology, 1983, 68, 60-69 
Stanley, A D High-tech will hurt women The New York Times, September 19, 1983, 133, 45,806 Sect A p. 19

Treiman, D I Occupational prestige in comparative perspective New York Academic Press, 1977

Treiman, D I , \& Hartman, H I Women, work and wages- Equal pay for jobs of equal value Washington, D C National Academy Press, 1981 